\title{
ВИЗНАЧЕННЯ ПРОФЕСІЙНИХ СТАТУСІВ СТАРШОКЛАСНИКІВ
}

Удк: 159.98:37.047

\section{Пиук Наталя}

Доктор медичних наук, професор, завідувач кафедри медичної психології та психіатрії з курсом післядипломної освіти Вінницького національного медичного університету імені М. Пирогова (Вінниия, Україна)

\section{Потоцька Ірина}

Кандидат психологічних наук, асистент кафедри медичної психології та психіатрії з курсом післядипломної освіти Вінницького національного медичного університету імені М. Пирогова (Вінниия, Україна)

\begin{abstract}
Анотація. $\quad$ с статті розглянуто актуальність дослідження професійного самовизначення особистості старшокласника. Емпіричне дослідження відбувається за допомогою тесту Дж. Марсіа «Визначення професійних статусів», щэо виділяє наступні професійні статуси: «невизначена професійна ідентичність», «нав'язана професійна ідентичність (здобута)», «мораторій (криза вибору) професійної ідентичності» та «сформована професійна ідентичність». Результати дослідження показали, що майже половина старшокласників знаходяться у кризі вибору майбутньої професії, тобто вагаються. Лише у 7\% досліджуваних професійна ідентичність є сформованою.

Ключові слова: професійна ідентичність, статус ідентичності, невизначена професійна ідентичність, нав'язана професійна ідентичність, мораторій професійної ідентичності, сформована професійна ідентичність.
\end{abstract}

Постановка проблеми. Останнє десятиліття українська освіта піддається постійному реформуванню спрямованому на індивідуалізацію, гуманізацію та професійне самовизначення сучасних старшокласників. Професійне самовизначення старшокласни- ка, з точки зору психології, є основою становлення особистості в цілому.

Психологія розглядає професійне самовизначення як найбільш значущий компонент професійного розвитку особистості, а також як критерій одного з етапів цього три- 
валого і складного процесу.

Завершується він тільки тоді, коли у людини сформується позитивне відношення до себе як до суб' єкта професійної діяльності. Тому свідомий вибір професії слід вважати показником сформованості професійного самовизначення i переходу його у нову фазу свого розвитку [1; с.73].

Аналіз останніх досліджень і публікацій. Проблема професійного самовизначення досліджується в працях Л. І. Божовіч, С. Л. Рубінштейна, Є. О. Клімова, М. С. Пряжникова, Л. Б. Шнейдер, Б.Г. Ананьєва, В. Д. Брагіна, Е. Заера. Серед сучасних досліджень відомі наступні дослідники В. І. Доротюк, Г. О. Корсун, Н. О. Мосол, С. О. Тарасюк та інші. Теоретичну та методологічну основу роботи складають фундаментальні дослідження проблеми професійного самовизначення, профорієнтації і профвідбору такими вченими, як О.О. Вайсбург, О. Ю. Голомшток, Є. А. Єндальцев, Є. О. Клімов, Є.М. Павлютенков, О. В. Мудрик, М. С. Пряжніков, О. С. Татенко, В. В. Синявський, С. Н. Чистяков, Б. О. Федоришин та ін.

Мета статті визначити статуси професійної ідентичності старшокласників.
Виклад основного матеріалу і peзультатів дослідження. Вибірку в нашому дослідженні становили учні 11-х класів Тростянецької середньої загальноосвітньої школи I -III ступенів №2 та Навчально-виховного комплексу «Середньої загальноосвітньої школи IIII ступенів №1-гімназія» у загальній кількості 58 осіб, віком від 15 - до 17 років, що і становить старший шкільний вік.

В роботі використано тест Дж. Марсіа «Визначення професійних статусів». Автор розробив статусну модель ідентичності, як методологічний план до еріксонівських теоретичних представлень 3 метою їх емпіричного вивчення. На сьогоднішній день дана модель набула самостійного значення. Дж. Марсіа виділив чотири статуси ідентичності (стани ідентичності) - це чотири варіанта закінчення кризи у віці від 18 до 21 року (для американської молоді).

Критеріями для виділення статусів виступали два параметри (дивись таблицю 1):

1) Наявність або відсутність кризи.

2) Прийняття зобов'язань за двома основними сферами функціонування: професія та ідеологія.

Критерії виділення статусів ідентичності

\begin{tabular}{|c|c|c|c|c|}
\hline \multirow{2}{*}{$\begin{array}{c}\text { Позииія віднос- } \\
\text { но професії та } \\
\text { ідеологї̈ }\end{array}$} & \multicolumn{4}{|c|}{ Статуси ідентичності } \\
\hline & $\begin{array}{l}\text { Сформована } \\
\text { ідентичність }\end{array}$ & $\begin{array}{c}\text { Здобута іден- } \\
\text { тичність }\end{array}$ & $\begin{array}{l}\text { Невизначена } \\
\text { ідентичність }\end{array}$ & Мораторій \\
\hline Криза & Пройшла & Відсутня & $\begin{array}{c}\text { Присутня або } \\
\text { відсутня }\end{array}$ & В кризі \\
\hline $\begin{array}{c}\text { Прийняття на } \\
\text { себе зобов'я- } \\
\text { зань }\end{array}$ & Присутнє & Присутне & Відсутнє & $\begin{array}{c}\text { Присутнє роз- } \\
\text { мито }\end{array}$ \\
\hline
\end{tabular}


Термін «криза» відноситься до того періоду великих зусиль в житті людини, коли вона роздумує, який вибрати професійний шлях (кар'єру) і яким цілям, цінностям, переконанням слід слідувати в житті. Взяття зобов'язань передбачає прийняття твердих рішень щодо вибору професії та ідеології, а також вироблення цільових стратегій для реалізації прийнятих рішень [3; с.306].

Можна виділити чотири статуси професійної ідентичності - «стани», у яких може перебувати учень у процесі професійного навчання:

$\diamond$ Невизначена професійна ідентичність. Стан характерний для старшокласників та студентів, які не мають міцних професійних цілей і планів, і при цьому не намагаються їх сформувати, вибудувати варіанти свого професійного розвитку. Найчастіше цей статус притаманний для молодих людей, батьки яких не хочуть або не мають часу проявляти активний інтерес до професійного майбутнього своїх дітей. Такий статус буває і у людей, які звикли жити тимчасовими бажаннями, недостатньо усвідомлюють важливість вибору майбутньої професії.

$\diamond$ Нав'язана професійна ідентичність (здобута) - людина має сформовані уявлення про своє професійне майбутнє, але вони нав'язані ззовні (наприклад, батьками або друзями) і не є результатом самостійного вибору. Цей стан характерний для людини, яка вибрала свій професійний шлях, але зробила це не шляхом самостійних роздумів, а прислухавшись до думки авторитетів. На якийсь час це, як правило, забезпечує комфортний стан, дозволяючи уникнути переживань $з$ приводу власного майбутнього, але немає ніякої гарантії, що обрана таким шляхом професія буде відповідати інтересам і здібностям самої людини. Мораторій (криза вибору) професійної ідентичності - людина усвідомлює проблему вибору професійного шляху і знаходиться в процесі пошуку адекватного рішення. Такий стан характерний для людини, що досліджує альтернативні варіанти професійного розвитку і активно намагається вийти 3 цього стану, прийнявши осмислене рішення про своє майбутнє. Ці юнаки та дівчата розмірковують про можливі варіанти професійного розвитку, приміряють на себе різні професійні ролі, прагнуть якомога більше дізнатися про різні спеціальності та шляхи їх отримання. На цій стадії нерідко складаються нестійкі відносини з батьками і друзями: повне взаєморозуміння може швидко змінюватися нерозумінням, і навпаки. Як правило, більша частина людей після «кризи вибору» переходять до стану сформованої ідентичності, рідше до нав'язаної ідентичності.

$\diamond$ Сформована професійна ідентичність професійні плани старшокласника досить чітко визначені, що стало результатом осмисленого самостійного рішення. Ці юнаки та дівчата характеризуються тим, що вони готові зробити усвідомлений вибір подальшого професійного розвитку або вже його зробили. У них присутня впевненість у правильності прийнятого рішення про їх професійне майбутнє. Цим статусом володіють ті юнаки і дівча- 
та, які пройшли через «кризу вибору» i самостійно сформували систему знань про себе і про свої професійні цінності, цілі і життєві переконання. Вони можуть усвідомлено будувати своє життя тому що визначилися, чого хочуть досягти.

$\diamond$

Метою даної методики $є$ визначення статусів професійної ідентичності.

Опитувальник складається із 20 пунктів, кожен з яких містить чотири варіанта відповіді: a,b,c,d. Потрібно вибрати той варіант, який найкраще виражає точку зору респондента. Можливо деякі варіанти здаються рівно- цінними, але потрібно вибрати найважливіший. Усі відповіді записуються у спеціальний бланк. Кожний варіант відповіді оцінюється у 1 або 2 бали за спеціальним «ключем». Далі підраховуються бали за чотирма шкалами: «Невизначена ідентичність», «Сформована ідентичність», «Здобута ідентичність», «Мораторій».

Результати проведеної методики представлені у таблиці 2.

Таблиця 2

Результати визначення професійної ідентичності

\begin{tabular}{|c|l|c|c|}
\hline № п/п & Тип професійної ідентичності & Кількість учнів & $\begin{array}{c}\text { Відсоткове відно- } \\
\text { шення }\end{array}$ \\
\hline 1. & Сформована (передчасна) ідентичність & 4 & $7 \%$ \\
\hline 2. & Мораторій & 26 & $45 \%$ \\
\hline 3. & Здобута ідентичність & 17 & $29 \%$ \\
\hline 4. & Невизначена ідентичність & 11 & $19 \%$ \\
\hline
\end{tabular}

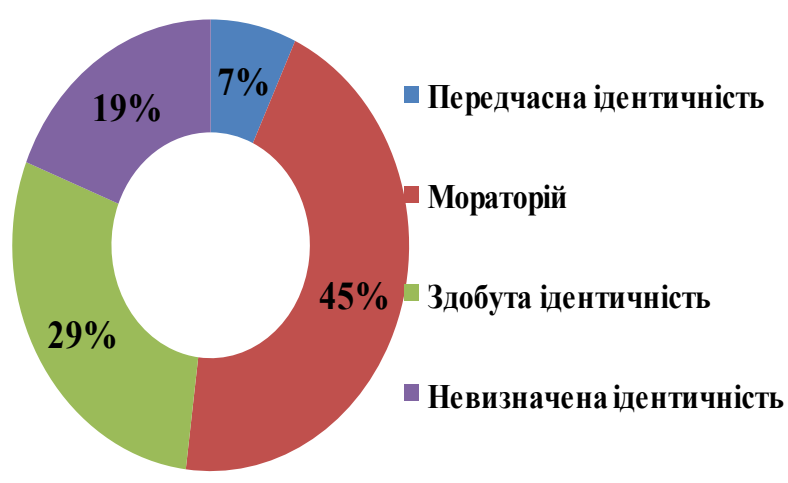

\section{Рис.1. Розподіл статусів професійної ідентичності серед старшокласників}


Як видно з рисунку 1, майже у половини досліджуваних яскраво представлений такий статус ідентичності як «мораторій» (у 45\%). Старшокласники віком від 15 до 17 років ще не можуть визначитися з вибором подальшого професійного шляху та знаходяться в процесі пошуку адекватного рішення. Причинами такого кризового стану можуть бути: велика кількість навчальних закладів та різноманітних спеціальностей що ускладнюють процес вибору майбутньої професії; складна економічна ситуація, що склалася в нашій країні, що в свою чергу ускладнює розуміння престижних та популярних професій.

Майже у третини вибірки (29\%) проявляється такий статус ідентичності як «здобута ідентичність». Обрання такого статусу професійної ідентичності свідчить про важливу роль батьків, родичів та референтної групи осіб при обранні майбутньої професії. Це є наслідком матеріальної залежності молоді від своїх батьків, адже саме вони будуть платити за навчання і відповідно до своїх можливостей і обирають навчальний заклад та майбутню спеціальність. Часто батьки бажають для дітей тієї ж професії що і у них. Це дає можливість ділитися досвідом зі своїм нащадком, допомогти йому у кар'єрному зростанні та бути по житті йому опорою, підтримкою та вчителем.

У $\quad 19 \%$ вибірки проявляється «невизначена ідентичність» як свідчення особистісної незрілості або відсутності мотивації щодо подальшого навчання.

Найменш проявленим стилем (7\%) є «сформована ідентичність». Такий низький відсоток свідчить про не готовність учнів 11 класів до здійснення повноцінного, усвідом- леного та самостійного професійного вибору.

Висновки. Більшість сучасних старшокласників, майже кожен другий, знаходяться у кризі вибору майбутньої професії. В такому стані вони шукають альтернативу та намагаються прийняти осмислене рішення щодо свого майбутнього. Такі старшокласники прагнуть якомога більше дізнатися про усі можливі спеціальності та шляхи їх отримання. Дана криза може призводити до порушення взаємостосунків з батьками у зв'язку із не підтриманням їх бачень на майбутнє. Як правило, велика частина людей після «кризи вибору» переходять до стану сформованої ідентичності.

\section{Перелік використаних джерел:}

1. Заєцьь I.В., Синявський В.В. Психологія професійного самовизначення особистості. / Психологія праці та управління. Особливості здійснення психологічної підтримки внутрішньо переміщених осіб на сучасному ринку праці: зб. матеріалів XI Наук. практ. конф. (м. Київ, 22 квітня 2015 р.) / [відп. ред. О.А. Ліщинська; упоряд. Г.А. Пріб, О.П. Смирнова, В.Ф. Колесниковата ін.]. - К. : ІПК ДСЗУ, 2015.-С.69-80.

2. Мосол Н.О., Іванова Л.С. Психологічні основи професійного самовизначення старшокласників. Доступний з http://www.nbuv.gov.ua/old_jrn/Soc_Gum/Vchdpu/ psy/2011_94/Mosol.pdf

3. Мачуська I.M. Дослідж ення рівня гот овност і до професійного самовизначення учнів старшого шкільного віку./Збірник наукових праць. - Випуск 16.Книга 2.- 2012.- C.302-312.

4.Сердюк Л. Психологічні особливост і професійного самовизначення старшокласників. Доступний 3: http:// social-science.com.ua/article/419 


\section{References (Transliteration):}

1. Zaets I. V., Sinyavskiy V.V. PsihologIya profesIynogo samoviznachennya osobistostI. / PsihologIya pratsI ta upravlInnya. OsoblivostI zdIysnennya psihologIchnoYi pIdtrimki vnutrIshno peremIschenih osIb na suchasnomu rinku pratsI: zb. materIalIv HI Nauk. prakt. konf. (m. KiYiv, 22 kvItnya 2015 r.) / [vIdp. red. O.A. LIschinska; uporyad. G.A. PrIb, O.P. Smirnova, V.F. Kolesnikovata In.]. - K. : IPK DSZU, 2015.-S.69-80.

2. Mosol N. O., Ivanova L.S. PsihologIchnI osnovi profesIynogo samoviznachennya starshoklasnikIv. Dostupniy z http://www.nbuv.gov.ua/old_jrn/ Soc_Gum/ Vchdpu/psy/2011_94/Mosol.pdf

3. Machuska I. M. DoslIdzhennya rInnya gotovnostI do profesIynogo samoviznachennya uchnIv starshogo shkIlnogo vIku./ZbIrnik naukovih prats. - Vipusk 16.Kniga 2.- 2012.- S.302-312

4. Serdyuk L. PsihologIchnI osoblivostI profesIynogo samoviznachennya starshoklasnikIv. Dostupniy z: http://socialscience.com.ua/article/419

\section{Pshuk Nataliya}

M.D., Professor of Psychiatry. Head of Department of Medical Psychology and Psychiatry with the course of postgraduate education, National Pirogov memorial Medical University, Vinnitsya (Ukraine)

\section{Pototska Iryna}

PhD in Psychological Sciences, assistant lecturer of Department of Medical Psychology and Psychiatry with the course of postgraduate education, National Pirogov memorial Medical University, Vinnitsya (Ukraine)

\section{DETERMINATION OF PROFESSIONAL IDENTITY OF SECOND SCHOOL'S STU- DENTS}

\section{ABSTRACT}

The article describes the relevance of the research status of modern professional school students. Identifies authors who study this issue in the present conditions change and reform of modern education system. Empirical research using the test was John. Marcia «The definition of professional status», which identifies the following professional status «uncertain professional identity», «imposed on professional identity (won)», «moratorium (the crisis of choice) professional identity» and «Formed professional identity».

The survey results show that nearly half manifests a modern high school professional status as a «moratorium» crisis characterized by the choice of profession, uncertainty and the search for alternatives. It describes the reasons for the existence of just such a status. The next most detected status is «acquired identity» as a result of the influence of parents and entourage for a decision on his future profession. Next in importance is «uncertain identity». These high school students still do not know who would like to be like their skills and abilities could be used in future activities. Only a very small number of senior professional identity manifested formed, indicating a clear vision of their future and will manifest as high motivation in teaching in higher education.

Keywords: professional identity, status, identity uncertain professional identity, professional identity imposed moratorium 
professional identity, professional identity formation.

\section{Пиук Наталья Григорьевна}

Доктор медиџинских наук, профессор, заведующий кафедрой медииинской психологии и психиатрии с курсом последипломного образования Винницкого национального медииинского университета имени Пирогова, г. Виннииа (Украина)

\section{Потоцкая Ирина Сергеевна}

Кандидат психологических наук, ассистент кафедры медицинской психологии и психиатрии с курсом последипломного образования Винницкого национального медиџинского университета имени Пирогова, город Винница (Украина)

\section{ОПРЕДЕЛЕНИЕ ПРОФЕССИАЛЬНЫХ СТАТУСОВ СТАРШЕКЛАССНИКОВ}

Аннотация. В статье рассмотрена актуальность исследования профессионального самоопределения личности старшеклассника. Эмпирическое исследование проходило с помощью теста Дж. Марсиа «Определение профессиональных статусов», в котором выделяются следующие профессиональные статусы: «неопределенная профессиональная идентичность», «навязанная профессиональная идентичность», «Мораторий (кризис выбора) профессиональной идентичности» И «Сформированная профессиональная идентичность». Результаты исследования показали, что почти половина старшеклассников находятся в кризисе выбора будущей профессии, то есть колеблются в своем выборе. Лишь у 7\% испытуемых профессиональная идентичность сформировалась.

Ключевые слова: профессиональная идентичность, статус идентичности, неопределенная профессиональная идентичность, навязанная профессиональная идентичность, мораторий профессиональной идентичности, сформированная профессиональная идентичность. 